American Journal of Environmental Sciences 8 (3): 297-303, 2012

ISSN 1553-345X

(C) 2012 Science Publications

\title{
Acceptance Towards Sustainable Agriculture among Contract Farmers and its Impingement Factors
}

\author{
${ }^{1}$ Hayrol Azril Mohamed Shaffril, ${ }^{1}$ Jeffrey Lawrence D'Silva, \\ ${ }^{1}$ Bahaman Abu Samah, ${ }^{2}$ Norsida Man, ${ }^{3}$ Jegak Uli and ${ }^{1}$ Azmariana Azman \\ ${ }^{1}$ Institute for Social Science Studies, \\ ${ }^{2}$ Faculty of Agriculture, \\ University Putra Malaysia, Malaysia \\ ${ }^{3}$ Faculty of Defence Studies and Management, \\ National Defence University of Malaysia, Malaysia
}

\begin{abstract}
Problem statement: Rising demands and needs for food nowadays have put a great pressure on our natural resources. Overuse of the environmental sources has been proven to have profound impact on both; the community and the environment. To solve such problem, sustainable agriculture has been suggested as one of the solutions. Undoubtedly, sustainable agriculture will supply adequate nutrition sources at the present and in the future to the community. In line with this, a lot of efforts have been put to embolden farmers to practise sustainable agriculture. Nonetheless, are the farmers accepting it in their farming routines? The answer of this query will fulfil the main objective of this study which is to discover the level of acceptance of contract farmers in Malaysia on sustainable agriculture. Additionally, socio-demographic factors that impinge the level of acceptance have become another objective for this study. Approach: This is a quantitative study where through a multi stage simple random sampling, a total of 326 contract farmers from four states in Malaysia were chosen as the respondents. Results: Analysis carried out has identified that contract farmers in Malaysia do have a high level of acceptance on sustainable agriculture. Apart from this, factors such as zone and races were identified to have significant difference with acceptance towards sustainable agriculture. Additionally, age was identified to have significant relationship with acceptance towards sustainable agriculture. Conclusion/Recommendation: Several discussions and recommendations have been highlighted and expectantly it can help the concerned parties to further strengthen contract farmers' acceptance towards sustainable agriculture.
\end{abstract}

Key words: Contract farmers, sustainable agriculture, socio-demographic factors, agriculture development

\section{INTRODUCTION}

Agriculture has been admitted as the fundamental tool in developing the socio-economic aspects of the community. Realizing this fact, in each of the Malaysia Plan (MP), agriculture has been accounted for its specific roles, particularly in bringing more money for the country and the local community. In the Ninth Malaysia Plan (RMK-9) for example, agriculture has been the third income generator for Malaysia. Apart from this, the government has come out with a number of high impact projects related to agriculture namely Agropolitan, High-Impact Project Zone Industry Aquaculture and contract farming.

Albeit many high impact projects were designed, another agriculture aspect that has been the focal focus of the government is sustainable agriculture. In recent days, the demands and needs for food have placed much pressure on the natural resources particularly on land and water. Such pressures were identified to have profound impacts on the community and sustainable agriculture has been suggested as one of the ways to combat such impacts. According to Gold (1999) sustainable agriculture is:

'An integrated system of plant and animal production practices having a site-specific application that will, over the long term: (1) satisfy human food and fiber needs; (2) enhance environmental quality and the natural resource base upon which the agricultural economy depends; (3) make the most efficient use of nonrenewable resources and on-farm 
resources and integrate, where appropriate, natural biological cycles and controls; (4) sustain the economic viability of farm operations and (5) enhance the quality of life for farmers and society as a whole'

Sustainable agriculture is one of the cores in ensuring adequate food supplies. Ignoring this would create massive problems which encompass a huge sum of money, energy and time to resolve it. Developed and developing countries are facing two different problems in sustainable agriculture. Developed countries are found to combat the problems of agriculture overproduction and comparatively developing countries are struggling to ensure their food production is sufficient enough to meet the needs of their growing populations. Albeit its importance on the continuity of food supply, additionally, sustainable agriculture is needed as according to Regmi and Weber (2000), it is an effective preparation for issues such as population pressure, subsistence agriculture, rural poverty, resources depletion, deforestation and land degradation.

Benefits of sustainable agriculture: It is important for us to preserve the environment in order to safeguard the supplies of resources for the future generation. Sustainable agriculture is an effective method in replenishing land and crucial sources such as soil, water and air to make them persistently available for the future generation. Doubtlessly, practising sustainable way of farming will enable the waste produced remains inside the farm ecosystem and lessen the risks of pollution to the external environment. Apart from this, sustainable agriculture abates the utilization of nonrenewable environmental resources and this profits the environment. Furthermore, it makes utmost use of the environment; nevertheless without causing any harm to it. Products produced do not contain any inorganic chemicals such as insecticides and pesticides. All of these impingement factors are among the drivers for farmers to accept the sustainable way of farming.

Sustainable agriculture is a profitable way of farming for farmers. Cost for things such as fertilizer and fossil fuel is lessen and able to increase their net income. Moreover, as a result, their dependence on government subsidies is reduced, thereby strengthening the socio-economic aspects of the rural communities. Apart from this, practising sustainable agriculture denotes that there are less reliant on the fossil fuel and minimize the transportation costs and eventually will reduce the overall cost needed to complete the farming process. Sustainable agriculture contributes to biodiversity as it produces different kinds of animals and plants.
Rotation of plants is compulsory practices in sustainable agriculture thus it produces enriched soil; minimize the risks of diseases and effective in controlling the pests.

Impingement factors of acceptance on sustainable agriculture: Acceptance towards sustainable agriculture among farmers is an important factor to be considered. Farmers who are the main actor in this industry should be emboldened to practise sustainable agriculture in order to ensure the environment still has something to offer for the future generation. There is abundance of studies that have revealed profound impacts of several factors on the acceptance towards sustainable agriculture. According to Souza et al. (1993) individual factors such as age has profound impact on individual decision to practice sustainable agriculture. In studies done by Jesus et al. (2008) and Hattam (2006) for example have detected that farmers 54 years and above were less likely to accept sustainable agriculture due to the facts that it involves a bigger number of workers and consume large investment in capital and knowledge. Furthermore, in a study done by Hall et al. (2009) found that education achievement can impinge their acceptance on sustainable agriculture. Hall et al. (2009) have further added that people perception particularly on the importance of agriculture sustainability to preserve the environment will determine their level of acceptance which denotes that people either with higher or lower education achievement has the same ability to reject or accept the sustainable agriculture. Apart from this, Hattam (2006) has accentuated on the farmers' attitude where farmers with positive attitude are found to have better acceptance towards sustainable agriculture compared to those with negative attitude. Souza et al. (1993) furthermore have found that environmental factor such as ground water quality has something to do with acceptance towards sustainable agriculture. Apart from this, impingement factors such as consistent consumer demand on chemical free or organic products, (2) potential cost savings and (3) personal beliefs (Souza et al., 1993). In another study conducted by Hall et al. (2009) emphasized that factors such as location do have profound impact on acceptance towards sustainable agriculture. Places with available land for agriculture and offer less polluted water, soil and air can drive farmers in practising sustainable agriculture. Additionally, acceptance on sustainable agriculture can be influenced by knowledge, skills and motivation of farmers and according to Ommani et al. (2009) it is the study of extensions to guarantee farmers will gain such needs. 
Table 1: Agriculture agencies and support services provided on the contract farming activities

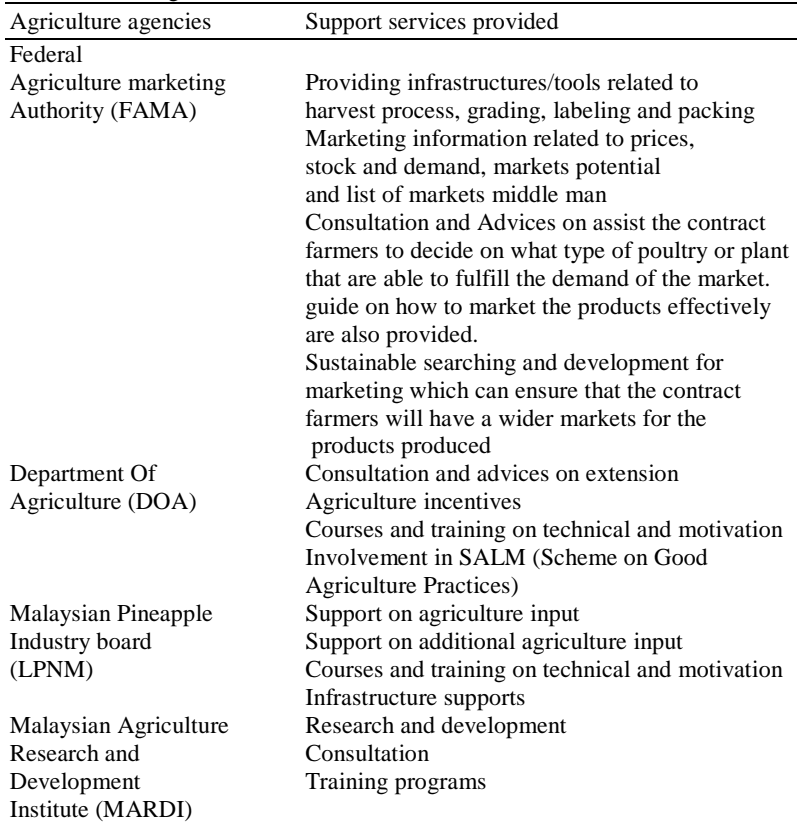

Contract farming in Malaysia: Contract farming is not a new industry in Malaysia. Since early 80s, the focus on this industry has been enlightened. Previously, the scheme was originally designed for poultry based broiler farm and then was broadened to other types of farming. Typically contract farming outputs are mainly based on crops and livestock. Nevertheless, the introduction of new form of contract farming such as leech rearing, worm rearing, bird nest and herbs has brought additional dimensions of this industry (D'Silva et al., 2010). Contract farming is applied within a number of giant companies in Malaysia. Federal Land Consolidation and Rehabilitation Authority or FELCRA for example has its contract farming scheme for cash crops and livestock (Bernama Newspaper, 2009) while NESTLE has its contract farming scheme focusing on the production of rice in Sarawak. Contract farming is one of the catalysts used by the government to assist the small and moderate scale agriculture entrepreneurs in ensuring that their agriculture productivity are able to come out with productive and profitable products. A number of government agencies such as Federal Agriculture Marketing Authority (FAMA), Department of Agriculture Malaysia (DOA), Farmers Organization Authority (FOA), Agrobank, Malaysia Agriculture Research Development Institute (MARDI) and Malaysia Pineapple Industry Board (LPNM), Ministry of Modernization of Agriculture Sarawak and Ministry of Agriculture and Food Industry Sabah have been attached to the contract farming activities. The markets of the contract farming products in Malaysia are very wide. Places such as Hypermarket and Supermarket such as Tesco and CAREFOUR, fresh fruit stall (GBBS), grocery (pasar malam, pasar tani), mini market and institution buyer such as Institute of Higher Learning. On top of it, some of the contract farming products is produced for the purpose of export. An increasing support on contract farming activities has been gained and a huge socio-economic benefits offered by this activities are among the main attraction of this increasing supports. Contract farming programs run by DOA for example is able to develop a total of 12,010 contract farmers involving areas of 20,208.5 ha. It is interesting to know that some of government initiative to alleviate poverty problem are applying contract farming concept.

Support services are persistently provided by the concern parties. Table 1 indicates to us the type of support services provided by a number of agriculture agencies in Malaysia

\section{MATERIALS AND METHODS}

This is a quantitative study where a total of 326 contract farmers were chosen as the respondents for this study. A multi stage random sampling was applied to gain the respondents required. At the first stage four zones were randomly selected (Sabah/Sarawak, east coast, northern and southern). Then at the second stage, through simple random sampling, a state was randomly selected; one state will be representing each zones. Based on this sampling, states such as Sabah (Sabah/Sarawak zone), Pahang (east coast zone), Kedah (Northern zone) and Johor (southern zone) were selected. In the third phases of sampling, again, the simple random sampling was employed to select the respondents of the study. The instrument used for this study was a questionnaire that was pre tested earlier. The pre-test has resulted in the cronbach alpha value of 0.911 , hence depicted that the instrument used was reliable and valid. For each question related to acceptance towards sustainable agriculture, the respondents were given a 5 likert-like scale where 1 representing strongly disagree, 2 representing disagree, 3 representing moderately agree, 4 representing agree and 5 representing strongly agree. The data collection process took almost eight months to be completed (April 2011 till December 2011). For each data collection process, three to four trained enumerators were hired to assist the researchers. For the analysis, SPSS was used where relevant and suitable analyses were performed to answer the objectives determined. 


\section{RESULTS AND DISCUSSION}

Findings: Table 2, illustrates on the demographic data of the contract farmers studied. It can be seen that majority of contract farmers within this study are exceeding 40 years old $(66.4 \%)$ compared to $9.8 \%$ whose age is between 20 to 30 years old. This is not surprising as the issue of inadequate backup generation in Malaysia is among the top issues raised by a number of local studies (Norsida, 2008; Hassan et al., 2009; Hassan and Shaffril, 2009; Shaffril et al., 2011). According to Norsida (2008), albeit admitting agriculture is a good business, young people especially youth, have less interest on agriculture and this thing happens due to the fact that youth is still considering agriculture as a second class job (Gidarakou, 1997). In line with studies done by Gidarakou (1997) and Adekanye (1984), female are the minority respondents $(30.1 \%)$ in this industry. Albeit great number of promotion done to attract more female in this industry, the impacts is still fuzzy. One of the causes that might contribute to less involvement of female in agriculture according to Gidarakou (1997) is the physicality demanded by this industry and their commitment towards their family. A large majority of the respondents were Malay $(73.0 \%)$ followed by Dusun (one of the main ethnics in Sabah) (24.5\%) and Chinese $(2.5 \%)$. Each of the zones was represented by almost equal number of respondents. The involvement of those with pre-university and university level of education (skills certificates, STPM, Diploma, Degree and Master) in this industry is still lacking; within this study, it can be found that only $4.6 \%$ of them were included in this group. In line with this, there are several reasons why those with higher level of education have less interest in agriculture. Samah et al. (2011) have identified that at the university level, students have a very high level of acceptance towards agriculture nonetheless D'Silva et al. (2010) has concluded that their negative perception and agriculture information illiteracy can be the reasons why their acceptance are keep reducing. Furthermore, status and standard of jobs are among the main determinants for educated people to choose their job. The mean income per month scored by the respondents were RM1,521.93, nonetheless, looking specifically at the results, $39.6 \%$ of them were still earning below RM500 per month and shadowed by poverty. In Malaysia the Economic Planning Unit has announced that those with earnings below than RM720 per month can be included in the poverty group. The mean score recorded for the experiences involving in contract farming was 8.03. Looking specifically at the results, majority of the respondents can be considered as new contract farmers where more than two fifth of them $(43.1 \%)$ have $1-3$ years' experience in contract farming. A total of $15.7 \%$ of them have more than 16 years' experience in this industry. Majority of the respondents have 4-7 family members within their house.

Table 3 depicts the germane data to the overall degree of acceptance towards sustainable agriculture among the contract farmers. To gain the overall degree, the cumulative mean score from 15 questions were calculated. Then, the cumulative mean score were grouped into three categories namely low (1.002.33), moderate (2.34-3.67) and high (3.68-5.00). Based on the mean score gained, it can be seen that the respondents studied do have a high level of acceptance towards sustainable agriculture. Besides accepting sustainable agriculture, data gained here reflected that contract farmers studied were aware on the importance to preserve the environment.

Table 2: The respondent's background

\begin{tabular}{|c|c|c|c|}
\hline Factors & Frequency & Percentage & Mean \\
\hline Age (years) & & & 49.5 \\
\hline $20-30$ & 32 & 9.80 & \\
\hline $31-40$ & 45 & 13.80 & \\
\hline $41-50$ & 91 & 27.90 & \\
\hline $51-60$ & 88 & 27.00 & \\
\hline$>60$ & 70 & 21.50 & \\
\hline \multicolumn{4}{|l|}{ Gender } \\
\hline Male & 228 & 69.90 & \\
\hline Female & 98 & 30.10 & \\
\hline \multicolumn{4}{|l|}{ Zone } \\
\hline Northern & 85 & 26.20 & \\
\hline East Coast & 80 & 24.50 & \\
\hline Southern & 81 & 24.80 & \\
\hline Sabah/Sarawak & 80 & 24.50 & \\
\hline \multicolumn{4}{|l|}{ Races } \\
\hline Malay & 238 & 73.00 & \\
\hline Dusun & 80 & 24.50 & \\
\hline Chinese & 8 & 2.50 & \\
\hline \multicolumn{4}{|l|}{ Level of Education } \\
\hline Never been to school & 59 & 18.10 & \\
\hline Primary school & 140 & 42.90 & \\
\hline PMR/SRP & 30 & 9.20 & \\
\hline SPM/SPMV & 82 & 25.20 & \\
\hline Skill certificates/STPM & 10 & 3.10 & \\
\hline Diploma & 4 & 1.20 & \\
\hline Degree/Master & 1 & 0.30 & \\
\hline Income per month & & & $1,521.93$ \\
\hline$<$ RM500 & 129 & 39.60 & \\
\hline RM501-RM1000 & 88 & 27.00 & \\
\hline$>$ RM1001 & 109 & 33.40 & \\
\hline $\begin{array}{l}\text { Experience as contract } \\
\text { farmers (years) }(n=324)\end{array}$ & & & 8.03 \\
\hline $1-3$ & 142 & 43.70 & \\
\hline $4-6$ & 63 & 19.40 & \\
\hline $7-10$ & 47 & 14.50 & \\
\hline $11-15$ & 22 & 6.80 & \\
\hline$>16$ & 51 & 15.70 & \\
\hline \multicolumn{4}{|l|}{$\begin{array}{l}\text { Number of household } \\
\text { members }\end{array}$} \\
\hline $1-3$ members & 69 & 21.20 & \\
\hline 4-6 members & 162 & 49.70 & \\
\hline$>7$ members & 95 & 29.10 & \\
\hline
\end{tabular}


Table 3:Overall mean of acceptance towards sustainable agriculture among contract farmers

\begin{tabular}{lcclc}
\hline Degree of acceptance & Frequency & Percentage & Mean & S.D \\
\hline Low (1.00-2.33) & 4 & 1.3 & 4.25 & 0.537 \\
Moderate (2.34-3.67) & 35 & 10.7 & & \\
High (3.68-5.00) & 287 & 88.0 & & \\
\hline
\end{tabular}

Table 4:Statements used to measure acceptance towards sustainable agriculture among contract farmers

\begin{tabular}{lll}
\hline I accept sustainable agriculture practices because & Mean & S.D \\
\hline $\begin{array}{l}\text { It offers consumers opportunity to practice } \\
\text { a healthy diet }\end{array}$ & 4.44 & 0.582 \\
It improves my health condition & 4.43 & 0.597 \\
$\begin{array}{l}\text { It increases awareness on the importance of } \\
\text { environmental preservation }\end{array}$ & 4.41 & 0.649 \\
$\begin{array}{l}\text { It contributes to the care and protection of } \\
\text { the resources for the future generation }\end{array}$ & 4.41 & 0.615 \\
It helps to produce quality goods & 4.41 & 0.686 \\
It helps to uplift the quality of life & 4.40 & 0.623 \\
It reduces the risks of environmental pollution & 4.34 & 0.726 \\
it produces crops that are not contaminated & 4.32 & 0.730 \\
It provides food security in the future & 4.29 & 0.824 \\
It strengthens my reputation and image among & 4.24 & 0.810 \\
my colleagues and the community & & \\
It aids in improving the quality of the water and soil 4.24 & 0.892 \\
It increases my profits & 4.17 & 0.763 \\
It uses natural fertilizer, crop rotation and & 4.16 & 1.010 \\
biological pest control & & \\
It reduces the cost for a long term period & 3.75 & 1.150 \\
It involves small investment in the future & 3.73 & 1.110 \\
\hline
\end{tabular}

Typically, in studies all around the world (Hattam, 2006; Hall et al., 2009; Ommani et al., 2009) it can be revealed that acceptance on sustainable agriculture among farmers keep increasing on and this study is in line with it.

Besides examining the overall degree of acceptance towards sustainable agriculture, this study was interested to examine specifically each of the questions included in the instrument. A total of 15 questions germane to the study were included. It is encouraging to know that all of the questions asked recorded a high level of mean score ranging from $\mathrm{M}=$ 3.75 to M 4.44. The highest mean score was recorded by the question of 'it offers consumers opportunity to practice a healthy diet' while the lowest mean score was recorded by the question of 'it reduces the cost for long time period'. Apart from this, questions related to 'it improves my health condition', it increases awareness on the importance of environmental preservation'; 'It contributes to the care and protection of the resources for the future generation'; 'it helps to produce quality goods' and 'it helps to uplift the quality of life' were also identified to score a good level of mean score (Table 4).

Comparison between selected independent variables and acceptance towards sustainable agriculture: In an attempt to discover the impingement factors on acceptance of contract farmers towards sustainable agriculture, independent t-test was performed. Referring to the data gained (Table 5), there was no significant difference identified in the factor of gender. This is concretely based on $\mathrm{M}=4.28, \mathrm{SD}=$ 0.542 for male and $\mathrm{M}=4.19, \mathrm{SD}=0.523 ; \mathrm{t}(326)=$ $1.418, \mathrm{p}=0.157$ for female. This reflects the possibility that both; male and female contract farmers have an equal level of acceptance.

The same procedure was applied in discovering any difference in the factor of level of education. For the purpose of analysis, the level of education studied was divided into two groups namely < PMR and >SPM. Those who have never been to school, possess primary school level of education and PMR certificates were included in the <PMR group while those with SPM/SPMV, Skill certificates/STPM, Diploma and Degree/Master level of education were included in the $>$ SPM group. Albeit there was difference on the mean score recorded between $\angle \mathrm{PMR}(\mathrm{M}=4.23)$ and $>\mathrm{SPM}(\mathrm{M}$ $=4.30)$, the $\mathrm{t}$ value recorded was too small $(\mathrm{t}=1.072)$ and the $\mathrm{p}$ value was 0.284 , hence reflecting that there was no significant different between these two groups.

However, things look different for the factor of race. There are three races studied, the Malay contract farmers, Chinese contract farmers and Dusun contract farmers. Nonetheless, for the purpose of analysis, the Dusun and Chinese contract farmers were combined. Based on $\mathrm{M}=4.17, \mathrm{SD}=0.541$ for Malay contract farmers and $\mathrm{M}=4.46, \mathrm{SD}=0.5465 ; \mathrm{t}$ $(326)=4.442, \mathrm{p}=0.0001$ for Dusun/Chinese contract farmers, thus reflecting that there was significant difference in acceptance towards sustainable agriculture among the two groups studied. Obviously, Dusun/Chinese contract farmers were those who have a better level of acceptance.

In term of discovering any significant difference on the factor of zone, ANOVA was performed. Based on the $F$ value $(4,326)=8.750, p<0.05$, has proven that there was a significant difference in acceptance towards sustainable agriculture between the four zones studied. Further analysis done through post hoc test has revealed that there was significant difference that occurred between Sabah/Sarawak contract farmers and East Coast contract farmers. Certainly, what has been found in Table 6 can be related to Table 5 as Sabah/Sarawak zone was fully represented by the Dusun people.

This study also attempts to identify any relationship that might occurs between acceptance towards sustainable agriculture and selected independent variables, inferential analysis through Pearson product-moment correlation was employed and data gained was depicted in Table 7. 
Table 5:Comparison between selected independent variables and acceptance towards sustainable agriculture using independent t-test

\begin{tabular}{lrrlll}
\hline Variables & $\mathrm{n}$ & Mean & $\mathrm{SD}$ & $\mathrm{t}$ & $\mathrm{p}$ \\
\hline Gender & & & & 1.418 & 0.157 \\
Male & 228 & 4.28 & 0.542 & & \\
$\begin{array}{l}\text { Female } \\
\text { Level of education }\end{array}$ & 98 & 4.19 & 0.523 & & \\
$\begin{array}{l}\text { PMMR } \\
>\text { SPM }\end{array}$ & 229 & 4.23 & 0.558 & & \\
Races & 97 & 4.30 & 0.484 & & \\
Malay & & & & 4.442 & 0.0001 \\
Dusun/Chinese & 238 & 4.17 & 0.541 & & \\
\hline
\end{tabular}

Table 6:Comparison between selected independent variables and acceptance towards sustainable agriculture using independent ANOVA

\begin{tabular}{lcccll}
\hline Variables & $\mathrm{n}$ & Mean & $\mathrm{SD}$ & $\mathrm{F}$ & $\mathrm{P}$ \\
\hline Zone & & & & 8.750 & 0.0001 \\
Northern & 85 & 4.26 & 0.555 & & \\
East coast & 80 & 4.07 & 0.516 & & \\
Southern & 81 & 4.19 & 0.561 & & \\
Sabah/Sarawak & 80 & 4.48 & 0.430 & & \\
\hline
\end{tabular}

Table 7:Relationship between selected independent variables and acceptance towards sustainable agriculture using Pearson Product Moment Correlations

\begin{tabular}{lll}
\hline Variables & $\mathrm{R}$ & $\mathrm{P}$ \\
\hline Age & -0.127 & 0.021 \\
Income per month & 0.017 & 0.759 \\
Household members & 0.033 & 0.256 \\
Experience as contract farmers & 0.090 & 0.104 \\
\hline
\end{tabular}

Analysis performed has discovered that out of four independent variables studied, only one independent variable namely age, was detected to have significant relationship with acceptance towards sustainable agriculture. Nonetheless, the strength of relationship detected was low. Factors such as income per month, household members and experience as contract farmers were identified to have no significant relationship with acceptance towards sustainable agriculture.

Within this study, it can be found that there was significant difference on the acceptance towards sustainable agriculture for the factors of race and zone. Dusun is very well known with their agricultural and forest products, has been found to have a better level of acceptance towards sustainable agriculture. Practising what they believe will be the key to create a better acceptance towards sustainable agriculture (Hall et al., 2009; Ommani et al., 2009; Bonny and Vijayaragavan, 2001). Comparatively, Dusun people were practising more sustainable agriculture thus reflecting why they have a better level of acceptance than other contract farmers. Several reasons have been related to this. First, Dusun people claimed that they were applying traditional methods way of farming and use less chemical fertilizer in their farms due to the fact that they believe that the environment are their 'friends' and should not be harmed. Results gained here is in line with study done by Genpan (2009) where according to him, sustainable agriculture and traditional way of farming are inter-related. Traditional farming routines depend almost fully on the nature and has minimum reliant on chemical and modern technology; hence those who practice traditional way of farming were also recognized as those who practice sustainable agriculture. Apart from this, it can be found that sustainable agriculture is one of the methods for farmers to preserve the traditional way of farming.

Second, the Dusun claimed that the traditional farming is more effective and productive than using the chemicals. FAO (2009), has concluded that traditional agriculture farmers through their traditional practices were able to maintain high levels of genetic resources for food and agriculture which generates a firm basis for sufficient food security for present and the future generation. Basically, what have been practised by the Dusun are contributing much to sustainability process as aspects such as ecosystem and landscape management, water management, soil conservation, biological control of pests and diseases, ecological agriculture and livestock practices and plant and animal breeding depend much on the nature.

Third, other contract farmers found stated that they are expecting the maximum productivity from the land, hence, denotes that they are focusing on the profits and quantity produced and will use any means to achieve this, including using the chemical things while the Dusun, not driven by profits and quantity and much satisfy with the moderate earnings from their productivity based on the facts that they do not want to harm their 'friends'. Additionally, besides using the chemical, the Dusun were identified to use the biological controls to protect their farming from the pests.

Age is another factor that was significantly related with acceptance towards sustainable agriculture. The negative correlation identified has brought a possibility that the older the contract farmers are, the lower their level of acceptance towards sustainable agriculture. This is not surprising as older people seem reluctant to accept sustainable agriculture due to more investment it needs in labour, knowledge and skills (Jesus et al., 2008; Hattam, 2006).

It is recommended that contract farmers in the east coast, northern and southern zones should be provided with extra courses and seminars on sustainable agriculture in order to enhance their acceptance towards sustainable agriculture. Besides, such courses and seminars should be focused on older contract farmers (0.0> 50 years). What have been practiced by the Dusun should be exposed to those in Peninsular Malaysia. Extension officers accounted in the Dusun 
areas should be given opportunity to expose the Dusun farming routines to their colleagues in the Peninsular. The way they practise their farming routine yet proven to be profitable, nonetheless it preserves their 'friends' as well.

\section{CONCLUSION}

Sustainable agriculture is one of the core keys in safeguarding the nation food supplies. It is heartening to know that majority of contract farmers studied were accepting sustainable agriculture. Specific analyses run have confirmed that the contract farmers accept sustainable agriculture due to its positive impacts on their diet, health status and providing sustainable food supplies for the future generation. Contract farmers from different zones and races were identified to have unequal level of acceptance towards contract farming, hence more specific courses and seminars germane to sustainable agriculture should be conducted as one of the tools to strengthen their acceptance on sustainable agriculture. Information exchange can be adept; people with a better level and knowledge on sustainable agriculture should share it with their contract farmers' colleagues.

\section{REFERENCES}

Adekanye, T.O., 1984. Women in agriculture in Nigeria: problems and policies for development. Women's Stud. Int. Forum, 7: 423-431. DOI: 10.1016/0277-5395(84)90013-X

Bernama Newspaper, 2009. FELCRA to expand contract farming programme. Malaysian National News Agency.

Bonny, B.P. and K. Vijayararagavan, 2001. Adoption of sustainable agricultural practices by traditional rice growers. J. Tropical Agric., 39: 151-156.

D’Silva, J.L., H.A.M. Shaffril., J. Uli and B.A. Samah, 2010. Acceptance and sustainability of contract farming among youth in Malaysia. Am. J. Agric. Biol. Sci., 5: 350-356. DOI: 10.3844/ajabssp.2010.350.356

FAO, 2009. FAO and traditional knowledge: The linkages with sustainability, food security and climate change impacts. United Nations Development Programme.

Genpan, L., 2009. Thought and practice of sustainable development in Chinese traditional agriculture. J. Sustain. Dev., 1: 97-109. DOI: 10.1108/17561370910915393

Gidarakou, I., 1997. Young women's attitudes towards agriculture and women's new roles in the Greek countryside: A first approach. J. Rural Stud., 15: 147158. DOI: 10.1016/S0743-0167(98)00054-0
Gold, M.V., 1999. Sustainable Agriculture: Definitions and Terms. 1st Edn., National Agricultural Library, Beltsville, Md., pp: 40.

Hall, T.J., J.H. Dennis, R.G. Lopez and M.I. Marshall, 2009. Factors affecting growers' willingness to adopt sustainable floriculture practices. J. Hortscience, 44: 1346-1351.

Hassan, M.S. and H.A.M. Shaffril, 2009. Internet usage among agro-based entrepreneurs: Can it affect productivity. J. Agric. Soc. Sci., 5: 61-66.

Hassan, M.S., S.M. Yassin, H.A.M. Shaffril, M.S. Othman and B.A. Samah et al., 2011. Receiving the agriculture information through mass media and interpersonal sources among the rural community. J. Agric. Biol. Sci., 3: 451-456, DOI: 10.3844/ajabssp.2011.451.461

Hattam, C., 2006. Adopting organic agriculture: An investigation using the Theory of Planned Behaviour. Proceeding of the International Association of Agricultural Economists in its series 2006 Annual Meeting, Aug. 12-18, Queensland, Australia.

Jesus, B.H., E.G. Maria and D. Pierre, 2008. Does intensity of change matter? Factors affecting adoption in two agri-environmental schemes. Economic Research Department.

Norsida, M., 2008. Youth perception towards agriculture and needs on agriculture education. J. Mala. Youth Dev., 1: 99-114.

Ommani, A.R., M. Chizari, C. Salmanzadeh and J.F.A. Hossaini, 2009. Predicting adoption behavior of farmers regarding on-farm Sustainable Water Resources Management (SWRM): Comparison of models. J. Sustain. Agric., 33: 595-616. DOI: 10.1080/10440040902997827

Regmi, P.P. and K.E. Weber, 2000. Problems to agricultural sustainability in developing countries and a potential solution: diversity. Int. J. Soc. Econ., 27: 788-801. DOI: 10.1108/03068290010335226

Samah, B.A., J.L. D'Silva, H.A.M. Shaffril and J. Uli, 2011. The impact of female university students' acceptance towards agriculture contract farming on Malaysian economy. Afr. J. Bus. Manage., 5: 6625-6631.

Shaffril, H.A.M., B.A. Samah, J.L. D'Silva and J. Uli, 2011. Global warming at the east coast zone of peninsular Malaysia. J. Agric. Biol. Sci., 6: 377383, DOI: 10.3844/ajabssp.2011.377.383

Souza, G.D., D. Cyphers and T. Phipps, 1993. Factors affecting the adoption of sustainable agricultural practices. J. Agric. Res. Econ. Rev., 5: 160-165. 